\title{
Votic Language
}

National Cancer Institute

\section{Source}

National Cancer Institute. Votic Language. NCI Thesaurus. Code C154193.

A Uralic language spoken by the Vote people of the Ing ria area of Finland. 